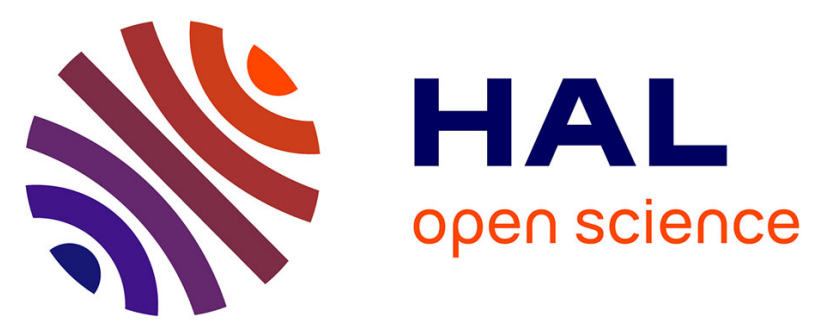

\title{
The Knowledge Structure and Core Journals Analysis of Crop Science Based on Mapping Knowledge Domains
}

\author{
Minjuan Liu, Lu Chen, Xue Yuan, Ting Wang, Yun Yan, Yuefei Wang
}

\section{To cite this version:}

Minjuan Liu, Lu Chen, Xue Yuan, Ting Wang, Yun Yan, et al.. The Knowledge Structure and Core Journals Analysis of Crop Science Based on Mapping Knowledge Domains. 9th International Conference on Computer and Computing Technologies in Agriculture (CCTA), Sep 2015, Beijing, China. pp.392-403, 10.1007/978-3-319-48354-2_39. hal-01614207

\section{HAL Id: hal-01614207 https://hal.inria.fr/hal-01614207}

Submitted on 10 Oct 2017

HAL is a multi-disciplinary open access archive for the deposit and dissemination of scientific research documents, whether they are published or not. The documents may come from teaching and research institutions in France or abroad, or from public or private research centers.
L'archive ouverte pluridisciplinaire HAL, est destinée au dépôt et à la diffusion de documents scientifiques de niveau recherche, publiés ou non, émanant des établissements d'enseignement et de recherche français ou étrangers, des laboratoires publics ou privés. 


\title{
The knowledge structure and core journals analysis of crop science based on mapping knowledge domains
}

\author{
Minjuan Liu ${ }^{1, \mathrm{a}}$, Lu Chen ${ }^{1, \mathrm{~b}}$, Xue Yuan ${ }^{1, \mathrm{c}}$, Ting Wang ${ }^{1, \mathrm{~d}}$, Yun Yan ${ }^{1, \mathrm{e}, *}$, Yuefei \\ Wang, ${ }^{1, \mathrm{f}}$ \\ ${ }^{1}$ Agriculture Information Institution of Chinese Academy of Agricultural Sciences,Beijing \\ 100081,China \\ aliuminjuan@caas.cn, ${ }^{b} 903618592 @$ qq.com, ${ }^{c}$ yuanxue@caas.cn, ${ }^{\mathrm{d}}$ wangting@caas.cn, \\ yanyun@caas.cn, ${ }^{\mathrm{f}}$ wangyuefei@caas.cn
}

\begin{abstract}
This paper aims at revealing the potential structure of crop science and core journals distribution to provide reference and help for crop research and journal work. On the basis of journal co-citation analysis this paper draws the co-citation map of Crop Science Journal by means of mapping knowledge domains and information visualization technology. 86 crop science journals can be roughly divided into two groups and each group of journals can be subdivided into two regions. Plant science (including plant physiology, plant ecology, plant cell etc.) and biology and chemistry (including biochemistry and molecular biology, gene and genetics etc.) are the mainstream research field of crop science. Crop production and soil science is another important branch of crop science. In addition, there is the phenomenon of cross integration between crop science and environment, horticultural science, plant protection, food processing, animal husbandry etc.
\end{abstract}

Keywords: international Journals, crop science, journal co-citation analysis, mapping knowledge domains

\section{Introduction}

Crop Science is one of the core disciplines of agricultural science, the theory and technology of which plays an important role in agriculture and rural economic development as an important support. In the 21st century, the situation of international Crop Science and technology had a huge change, which is penetrated continually by the bio-technology and information technology . The combination of high-tech and traditional technology promote the rapid development of crop science and technology ${ }^{[1]}$. The rapidly change of technological development brings crop science with opportunities and challenges. If grasp the subject development dynamics, we can get opportunities in the fierce competition. Scientific researchers always want to publish the new results and findings as soon as possible to achieve the occupation of frontier research in this field, attention of academia and peer recognition and so on. Therefore, knowledge of paper, to some extent, represents the latest research level 
when scientific papers published in the literature. Especially in those influential journals, many outstanding scientists of the world publish high-level scientific papers. Therefore, an core journal is not only an important media to disseminate research results, but also through the periodical analysis, it can help researchers to quickly understand the current research and grasp the latest trends.

Journals without external links can be organically linked by Journal co-citation analysis, which can reveal the relationship of interdependence and cross between journals, determine the professional scope, and help to identify core journals. The combination of Journal co-citation analysis and mapping knowledge domains can show up potential subject structure and power distribution of a field in a visually intuitive graph. The journals with a closer relationship concentrate together to form a different cluster result of different research directions and fields, which vividly depict the subject structure and core journals of the field ${ }^{[18]}$. Journal co-citation analysis started to develop on the basis of literature co-citation analysis. The concept of " literature Co-citation " was put forward in 1973 by the American intelligence scientist Henry Small ${ }^{[2]}$, after their studies were the first to carry out in 1974, extensive cocitation analysis followed up. In the later co-citation analysis, most of the research is literature co-citation analysis and author co-citation analysis represented by Small and White ${ }^{[3-9]}$. There were a lot of co-citation analysis and empirical research at home and abroad, but journal co-citation analysis and empirical research is not too much. For example, in 1991, McCain used journal co-citation analysis for practice to analyze the economics scholarly journals ${ }^{[10]}$; in 2000 , Ding, Y use journal co-citation analysis and visualization to study the development process of Intelligence retrieves during 1987-$1997^{[11]}$; in 2003, Tsay, MY visualized of the semiconductor areas with journal cocitation analysis ${ }^{[12]}$; in 2004, Liu Zao studied the literature of urban planning and visualized document structure with journal co-citation analysis ${ }^{[13]}$; in 2005 , Marshakova Shaikevich, I. used journal co-citation analysis and visualization in the subject of women's studies and library and information science, and pointed out the distribution of its subject areas ${ }^{[14]}$; in China, in 2006, Hou H.Y. used co-citation analysis and draw the science map of international metrology core journals ${ }^{[15]}$; in 2008 , Qiu J. P., Zhao W. H. used co-citation cluster analysis and core-periphery model to mainly analyze the 21 editing and publishing journals and determine the core journals of the discipline ${ }^{[16]}$;in 2009, Zhao Y. respectively used journal co-citation analysis and draw knowledge maps of Library and Information Science and biological hydrogen production ${ }^{[17-19]}$; in 2009 , Qin C. J. draw the knowledge map of the relationship between agricultural history of China and neighboring discipline based on journal co-citation analysis ${ }^{[20]}$, in 2010 , Liang Y. X. et al. used journal co-citation analysis method to learn the status of citation analysis discipline ${ }^{[21]}$.

Although there is relatively little research on journal co-citation analysis, but it is not only an effective way to research subjects and the structure and characteristics of literature, but also has its unique in the study of the overall discipline structure and the nature and characteristics of professional journals ${ }^{[22]}$. However, in the previous studies, there were more empirical research on the library and information science, and lacked application and validation in other fields, especially in the agricultural area; Also, the selecting target journals of co-citation analysis more dependent on existing database journals category or used the way of the keywords retrieval, so it can not be used in the field whose journals classification are not covered in database or can not 
use keywords retrieval. In this paper, it delineates the core journals gradually spreading from a single female parent journal based on citation analysis, in order to try to expand the applied disciplines of journal co-citation analysis, use visualization techniques to draw crop science map on the basis of the journal co-citation analysis of crop science journals. On the one hand, it can help researchers to understand Crop science knowledge structure and research focus. On the other hand, it can help researchers to know the characteristics of the journals and give reference for selecting the appropriate journal to submit the article.

\section{Data source and methods}

The research data are all from the Science Citation Index Expanded database of Thomson Scientific, The last update time is May 2013.

This study uses the journal co-citation analysis methods to reveal the interdependence cross relationship between journals, what's more, with the emerging international method of mapping knowledge domain and information visualization technology, drawing the journal co-citation map of crop science to vividly reveal the structure of the crop science core journals groups. The mainly methods include factor analysis, cluster analysis and multidimensional scaling, which the factor analysis by principal components analysis and varimax orthogonal rotation, cluster analysis by Hierarchical Clustering and Multidimensional Scaling by ALSCAL. The research combined two analytical approaches, which are bibexcel and SPSS for obtaining visualizing information of crop science.

Analysis steps:

First, selecting CROP SCIENCE as the female parent, which is the most important journal in the field of the crop science, by the method of single co-citation analysis, there are 2008 papers with 78121 citations in CROP SCIENCE from 2008 to May 2013 were analyzed and evaluated.

Second, selecting the journals which are higher cited by Crop Science for further cocitation analysis, there are 5819 papers with 240823 citations in these journals from 2008 to May 2013, then 98 journals which the cited frequency over 300 times among these journals are chosen to do a further analysis.

Last, cleaning the data of 98 journals, and finally choosing 86 journals to do the cocitation analysis, which are much more important journals in the field of crop science. To establish co-citation matrix with the data of 86 journals by Bibexcel, then use the matrix do some factor analysis, cluster analysis and Multidimensional Scaling by SPSS to draw the journal co-citation map of Crop Science with 86 journals, which can vividly reveal the relationship between journals and disciplinary structure of Crop Science. 


\section{Results and Discussion}

\subsection{Parental journal and citation analysis}

The parental journal "CROP SCIENCE" which was founded in 1997, the impact factor is 1.513, published by the Crop Science Society of America (CSSA). The journal publishes crop genetics and breeding; crop physiology and metabolism; crop ecology, crop production and management; seed physiology, seed production and technology; lawn learning; genomics, molecular genetics and biotechnology; plant genetics resources and pest control and other aspects and original research papers. The journal is indexed in SCI belongs to Q2, covers most fields of crop science and well-known in crop science. Therefore, this study chosen "CROP SCIENCE" as the parental journal, which can be a good representation of crop science.

Through citation analysis, there were 2736 journals cited by "CROP SCIENCE" ,the total citation frequency is 62950 times. In Table 1, the top 7 journals which were cited by CROP SCIENCE more than 1000 times are listed.

Table 1. Top 7 journals cited by CROP SCIENCE

\begin{tabular}{ccl}
\hline Rank & Cited frequency & Cited journal \\
\hline 1 & 11483 & CROP SCI \\
2 & 3905 & THEOR APPL GENET \\
3 & 2576 & AGRONOMY JOURNAL \\
4 & 1658 & EUPHYTICA \\
5 & 1484 & GENETICS \\
6 & 1304 & PLANT PHYSIOL \\
7 & 1168 & FIELD CROP RES
\end{tabular}

"CROP SCIENCE", "THE THEORETICAL AND APPLIED GENETICS", "THE AGRONOMY JOURNAL " and " EUPHYTICA " are cited by "CROP SCIENCE" more than 1500 times, the total cited frequency can reach 19622, accounting for $31.17 \%$ of all journal, and "CROP SCIENCE", its self-cited frequency is 11483 times and accounts for $18.24 \%$. Therefore, this study chosen the 4 journal as the parental journal to do further co-citation analysis to identify the important journals in the field of crop science.

Between 2008 and May 2013, these 4 journals has published 5819 papers with 240823 citations, there were 7113 journals cited by these 4 journals and the total cited frequency is 198362 times. Table 2 gives 98 journals which were cited more than 300 . It's necessary to clean the data of 98 journals, merge the same journals, eliminate the 
review journals and the journal that was not indexed in SCI, eventually retained 86 journals to do co-citation analysis.

Table 2. 98 journals cited more than 300 by 4 parental journals

\begin{tabular}{|c|c|c|c|c|c|c|c|}
\hline \multirow[b]{2}{*}{ Rank } & \multicolumn{2}{|r|}{ Cited } & \multirow[b]{2}{*}{ Journal ID } & \multirow[b]{2}{*}{ Rank } & \multirow[b]{2}{*}{ Cited journal } & \multirow{2}{*}{$\begin{array}{c}\text { Cited } \\
\text { frequency }\end{array}$} & \multirow[b]{2}{*}{ Journal ID } \\
\hline & Cited journal & frequency & & & & & \\
\hline 1 & CROP SCI & 19947 & a25 & 50 & GENOME RES & 588 & a35 \\
\hline 2 & THEOR APPL GENET & 18898 & a94 & 51 & J CEREAL SCI & 586 & a47 \\
\hline 3 & AGRON J & 8868 & a6 & 52 & PLANT PATHOL & 583 & a83 \\
\hline 4 & GENETICS & 6804 & a33 & 53 & AM J BOT & 573 & a7 \\
\hline 5 & EUPHYTICA & 6575 & a28 & 54 & COMMUN SOIL SCI PLAN & 563 & a24 \\
\hline 6 & PLANT PHYSIOL & 3447 & a84 & 55 & ADV AGRON & 563 & a2 \\
\hline 7 & P NATL ACAD SCI USA & 3047 & a70 & 56 & ANNU REV PHYTOPATHOL & 558 & a11 \\
\hline 8 & GENOME & 2927 & a34 & 57 & PLANT CELL ENVIRON & 549 & a76 \\
\hline 9 & FIELD CROP RES & 2806 & a31 & 58 & MOL ECOL & 535 & a61 \\
\hline 10 & PLANT BREEDING & 2443 & a73 & 59 & MOL GEN GENET & 527 & a62 \\
\hline 11 & PHYTOPATHOLOGY & 2414 & a72 & 60 & J ANIM SCI & 523 & a46 \\
\hline 12 & PLANT DIS & 2290 & a79 & 61 & J ECON ENTOMOL & 522 & a49 \\
\hline 13 & MOL BREEDING & 2075 & a60 & 62 & J SCI FOOD AGR & 518 & a56 \\
\hline 14 & PLANT CELL & 1985 & a75 & 63 & ANN APPL BIOL & 506 & a8 \\
\hline 15 & SCIENCE & 1860 & a89 & 64 & SOIL TILL RES & 504 & a92 \\
\hline 16 & PLANT J & 1821 & a80 & 65 & ACTA HORTIC & 460 & a1 \\
\hline 17 & J EXP BOT & 1688 & a51 & 66 & GENOMICS & 456 & a36 \\
\hline 18 & SOIL SCI SOC AM J & 1674 & a91 & 67 & WEED TECHNOL & 454 & a98 \\
\hline 19 & Crop \& Pasture Science & 1594 & a14 & 68 & J PLANT NUTR & 434 & a53 \\
\hline 20 & CAN J PLANT SCI & 1568 & a21 & 69 & MOL BIOL EVOL & 424 & a59 \\
\hline 21 & PLANT MOL BIOL & 1299 & a81 & 70 & J DAIRY SCI & 419 & $\mathrm{a} 48$ \\
\hline 22 & PLANT SOIL & 1273 & a86 & 71 & BIOMETRICS & 415 & a18 \\
\hline 23 & J HERED & 1217 & a52 & 72 & T ASAE & 409 & a93 \\
\hline 24 & NATURE & 1210 & a67 & 73 & PLANT CELL PHYSIOL & 401 & a77 \\
\hline
\end{tabular}




\begin{tabular}{|c|c|c|c|c|c|c|c|}
\hline Rank & Cited journal & $\begin{array}{l}\text { Cited } \\
\text { frequency }\end{array}$ & $\begin{array}{l}\text { Journa } \\
1 \text { ID }\end{array}$ & Rank & Cited journal & $\begin{array}{l}\text { Cited } \\
\text { frequency }\end{array}$ & $\begin{array}{l}\text { Journa } \\
1 \text { ID }\end{array}$ \\
\hline 25 & ANN BOT-LONDON & 1106 & a9 & 74 & PLANT CELL REP & 398 & a78 \\
\hline 26 & HORTSCIENCE & 1089 & $\mathrm{a} 40$ & 75 & ANNU REV PLANT PHYS & 381 & a13 \\
\hline 27 & NUCLEIC ACIDS RES & 1066 & a69 & 76 & WEED RES & 378 & a96 \\
\hline 28 & HEREDITY & 925 & a39 & 77 & AGR ECOSYST ENVIRON & 378 & a3 \\
\hline 29 & J ENVIRON QUAL & 904 & a50 & 78 & AGR FOREST METEOROL & 370 & $\mathrm{a} 4$ \\
\hline 30 & GENET RESOUR CROP EV & 900 & a32 & 79 & PLANT MOL BIOL REP & 369 & a82 \\
\hline 31 & NEW PHYTOL & 861 & a68 & 80 & J AGRON CROP SCI & 368 & $\mathrm{a} 43$ \\
\hline 32 & TRENDS PLANT SCI & 854 & a95 & 81 & NAT REV GENET & 368 & a66 \\
\hline 33 & NAT GENET & 839 & a65 & 82 & ANN EUGENICS & 362 & a10 \\
\hline 34 & J AGR FOOD CHEM & 794 & a41 & 83 & J AM OIL CHEM SOC & 361 & a44 \\
\hline 35 & J AM SOC HORTIC SCI & 794 & a45 & 84 & REMOTE SENS ENVIRON & 354 & a88 \\
\hline 36 & J AGR SCI & 782 & $\mathrm{a} 42$ & 85 & SOIL BIOL BIOCHEM & 353 & $\mathrm{a} 90$ \\
\hline 37 & MOL GENET GENOMICS & 727 & a63 & 86 & AUST J PLANT PHYSIOL & 352 & a16 \\
\hline 38 & J PROD AGRIC & 700 & a55 & 87 & AUST J EXP AGR & 347 & a15 \\
\hline 39 & PLANT SCI & 699 & a85 & 88 & AGR WATER MANAGE & 334 & a5 \\
\hline 40 & MAYDICA & 697 & a58 & 89 & ANNU REV PLANT BIOL & 326 & a12 \\
\hline 41 & EUR J AGRON & 680 & a29 & 90 & J PLANT PHYSIOL & 326 & a54 \\
\hline 42 & CURR OPIN PLANT BIOL & 660 & a26 & 91 & CAN J PLANT PATHOL & 316 & a20 \\
\hline 43 & BIOINFORMATICS & 653 & a17 & 92 & HEREDITAS & 310 & a38 \\
\hline 44 & WEED SCI & 644 & a97 & 93 & CAN J SOIL SCI & 307 & a22 \\
\hline 45 & PHYSIOL PLANTARUM & 643 & a71 & 94 & ECON BOT & 306 & a27 \\
\hline 46 & MOL PLANT MICROBE IN & 643 & a64 & 95 & Plant Breeding Reviews & 304 & a74 \\
\hline 47 & CEREAL CHEM & 629 & $\mathrm{a} 23$ & 96 & GRASS FORAGE SCI & 304 & a37 \\
\hline 48 & BREEDING SCI & 615 & a19 & 97 & J SOIL WATER CONSERV & 300 & a57 \\
\hline 49 & PLANTA & 603 & a87 & 98 & EUR J PLANT PATHOL & 300 & a30 \\
\hline
\end{tabular}




\subsection{Journal co-citation analysis and map knowledge domain}

\section{1) Journal co-citation matrix}

By bibexcel to count the cited frequency of the 86 journals, and to establish journal co-citation matrix, that is the original matrix, which laid a foundation to further reveal the relationship and structural characteristics between journals(Fig 1. 86 journal cocitation matrix). The matrix is a symmetric matrix, is co-diagonal journal citations, diagonal value is 0 , the matrix range is between $0-2379$. Meanwhile, transform the original matrix into Pearson correlation matrix as a similarity matrix, where similarity is measured by the correlation coefficient, the positive correlation is stronger, the two journals of the field of study or research is more similar, also showed that more similar academic backgrounds. (Fig 1.)

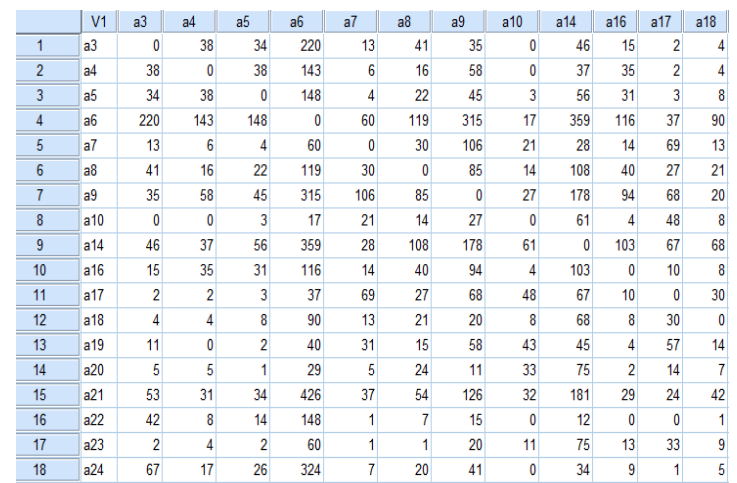

(a) Original matrix

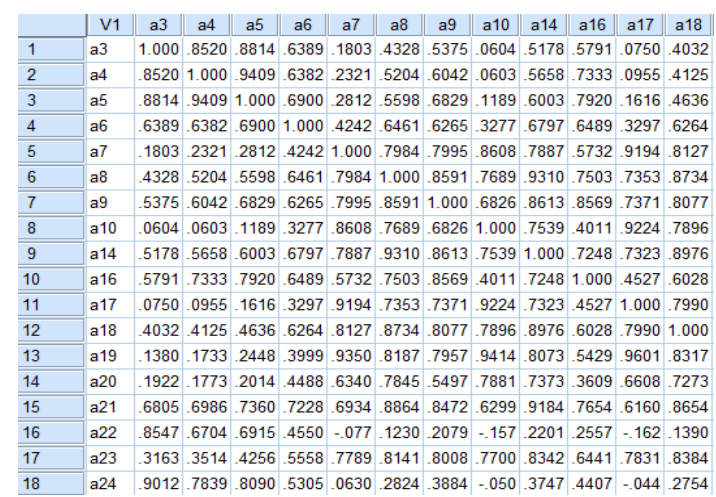

(b) Pearson correlation matrix

Fig.1. 86 journals co-citation matrix (parts) 


\section{2) Factor analysis}

On the basis of the Multidimensional Scaling, this study combined factor analysis and cluster analysis to supplement and improve the multidimensional scaling. This study did a principal components analysis on the Pearson correlation matrix of 86 journals by SPSS, It extract three main components factors and cumulative variance reached $86.709 \%$, which means three components factors have been able to explain the information contained in all variables well. TABLE 3 make a list of variables (journals) which factor loading is over 0.7.

Table 3. Variables (journals) which factor loading is over 0.7

\begin{tabular}{|c|c|c|c|c|c|c|c|c|c|}
\hline & Rank & $\begin{array}{l}\text { Journal } \\
\text { ID }\end{array}$ & $\begin{array}{l}\text { Factor } \\
\text { loading }\end{array}$ & Rank & $\begin{array}{l}\text { Journal } \\
\text { ID }\end{array}$ & $\begin{array}{l}\text { Factor } \\
\text { loading }\end{array}$ & Rank & $\begin{array}{l}\text { Journal } \\
\text { ID }\end{array}$ & $\begin{array}{l}\text { Factor } \\
\text { loading }\end{array}$ \\
\hline \multirow{18}{*}{ Factor1 } & 1 & a82 & .978 & 19 & a89 & .927 & 37 & a58 & .813 \\
\hline & 2 & a63 & .974 & 20 & a80 & .924 & 38 & a77 & .813 \\
\hline & 3 & a35 & .974 & 21 & a75 & .917 & 39 & a68 & .807 \\
\hline & 4 & a17 & .973 & 22 & a7 & .917 & 40 & a72 & .806 \\
\hline & 5 & a65 & .970 & 23 & a34 & .916 & 41 & a94 & .772 \\
\hline & 6 & a69 & .968 & 24 & a70 & .909 & 42 & a23 & .769 \\
\hline & 7 & a66 & .965 & 25 & a64 & .908 & 43 & a18 & .769 \\
\hline & 8 & a59 & .965 & 26 & a32 & .891 & 44 & a51 & .763 \\
\hline & 9 & a36 & .964 & 27 & a85 & .890 & 45 & a79 & .758 \\
\hline & 10 & a19 & .964 & 28 & a78 & .890 & 46 & a83 & .752 \\
\hline & 11 & a61 & .947 & 29 & a73 & .881 & 47 & a87 & .748 \\
\hline & 12 & a39 & .947 & 30 & a33 & .871 & 48 & a25 & .747 \\
\hline & 13 & a52 & .944 & 31 & a27 & .864 & 49 & a49 & .746 \\
\hline & 14 & a67 & .941 & 32 & a84 & .851 & 50 & a30 & .728 \\
\hline & 15 & a10 & .940 & 33 & a28 & .843 & 51 & a40 & .724 \\
\hline & 16 & a38 & .937 & 34 & a45 & .833 & 52 & a9 & .703 \\
\hline & 17 & a81 & .936 & 35 & a41 & .815 & 53 & a14 & .700 \\
\hline & 18 & a60 & .930 & 36 & a47 & .814 & & & \\
\hline
\end{tabular}




\begin{tabular}{llllllllll}
\hline & $\mathbf{1}$ & $\mathrm{a} 3$ & .958 & $\mathbf{8}$ & $\mathrm{a} 88$ & .919 & $\mathbf{1 5}$ & $\mathrm{a} 29$ & .827 \\
Factor2 & $\mathbf{2}$ & $\mathrm{a} 24$ & .951 & $\mathbf{9}$ & $\mathrm{a} 53$ & .906 & $\mathbf{1 6}$ & $\mathrm{a} 37$ & .816 \\
& $\mathbf{3}$ & $\mathrm{a} 90$ & .949 & $\mathbf{1 0}$ & $\mathrm{a} 91$ & .900 & $\mathbf{1 7}$ & $\mathrm{a} 86$ & .811 \\
& $\mathbf{4}$ & $\mathrm{a} 92$ & .940 & $\mathbf{1 1}$ & $\mathrm{a} 5$ & .857 & $\mathbf{1 8}$ & $\mathrm{a} 48$ & .717 \\
& $\mathbf{5}$ & $\mathrm{a} 50$ & .935 & $\mathbf{1 2}$ & $\mathrm{a} 4$ & .843 & $\mathbf{1 9}$ & $\mathrm{a} 96$ & .714 \\
& $\mathbf{6}$ & $\mathrm{a} 57$ & .922 & $\mathbf{1 3}$ & $\mathrm{a} 98$ & .839 & $\mathbf{2 0}$ & $\mathrm{a} 43$ & .705 \\
\hline Factor3 & $\mathbf{7}$ & $\mathrm{a} 22$ & .922 & $\mathbf{1 4}$ & $\mathrm{a} 97$ & .829 & & & \\
\hline
\end{tabular}

\section{3) Cluster analysis}

Meanwhile, this study did a cluster analysis on these 86 journals to further examine the similarity between the journals to supplement multidimensional scaling. Similar to factor analysis, the study choose Hierarchical Clustering to analysis the Pearson correlation matrix of 86 journals by SPSS. Figure 2 shows the result of cluster analysis. It's obviously to see that these 86 journals is better to classified into two clusters. 


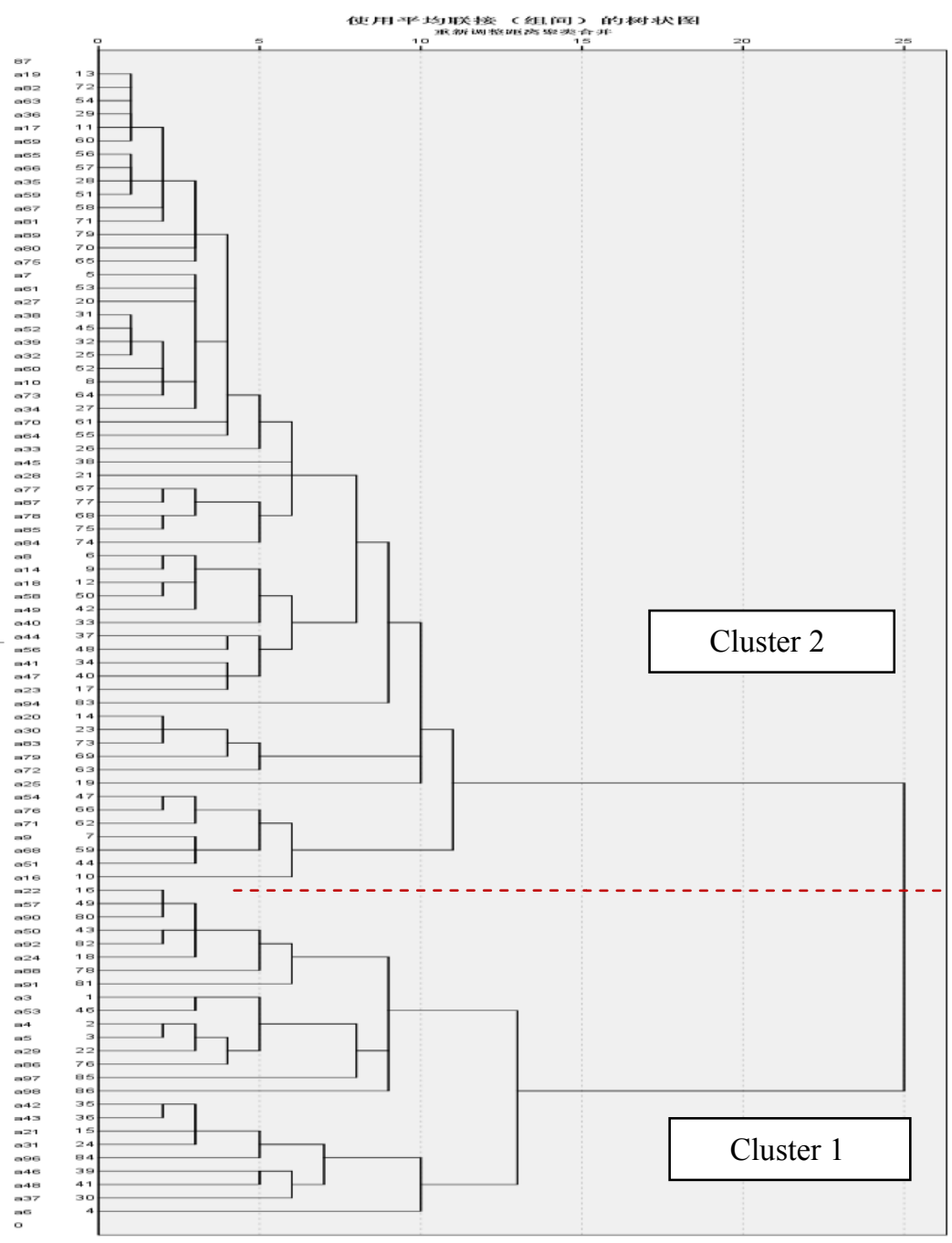

Fig.2. Hierarchical clustering tree diagram of 86 journals

\section{4) Multidimensional scaling analysis}

In order to reveal the affinities between journals and further determine the discipline structure of journals in crop areas, we carried multidimensional scaling analysis by putting the journal similarity matrix into SPSS, which can display the relationship between the original high-dimensional data in low-dimensional space. As the picture 3 , each dot represents a journal, and the location of periodicals show similarity (common disciplines or methods, etc.) between journals. The more similar the more 
together, and then form a knowledge group. In the knowledge group, the journal which has the closest relation with other point is in the middle of the journal position map, which shows that it is the core of knowledge group; the other hand, more in the periphery.

On the basis of the results of the factor analysis and cluster analysis, we draw the cocitation multidimensional scaling analysis diagram of 86 journals, shown in Figure 3. The value of stress is 0.03653 and RSQ is 0.99662 , so it reflects a very good fitting degree. The 86 journals are clearly divided into two parts, group 1 includes 26 journals, and group 2 includes 60 journals.

The group 1 can be divided into two parts. A1 has the most journals, which mainly includes the journals of crop production, soil science, agricultural resources and the environment and other related areas. The AGRON J, SOIL SCI SOC AM J, PLANT SOIL and some journals are the representations of this area, reflecting the inseparable relationship between crops and soil, water and environment. A2 area includes several agricultural comprehensive journals, and FIELD CROP RES is typical representation, which focus on crop production and cultivation, and become the connection of Journal group 1 and group 2.

The Group 2 can also be subdivided into two areas. B1 contains many journals which have tight connection and short distance from the origin, and some journals highly cited by the parental journal focused on here, which proves that this area is a core area concentrating crop science journals, covering the most important branches of Crop Science. It mainly includes the journals of crop genetics and breeding, plant science, biochemistry and molecular biology, gene and genetics, which attract more attention of crop science researchers and is the most core journals. The journal of CROP SCI, THEOR APPL GENET, GENETICS, EUPHYTICA, PLANT BREEDING, GENOME, P NATL ACAD SCI USA, PLANT PHYSIOL, PHYTOPATHOLOGY, PLANT DIS and other journals are the representation. From the view of position ,B2 likes the bridge of journals group 2 and group 1, which has more closely relation with A2, including the journals more closer to A2 which has Crop \& Pasture Science as a representative of agriculture comprehensive journals, also including the journals of ANN BOT-LONDON and HORTSCIENCE as a representative of botany and horticulture. 


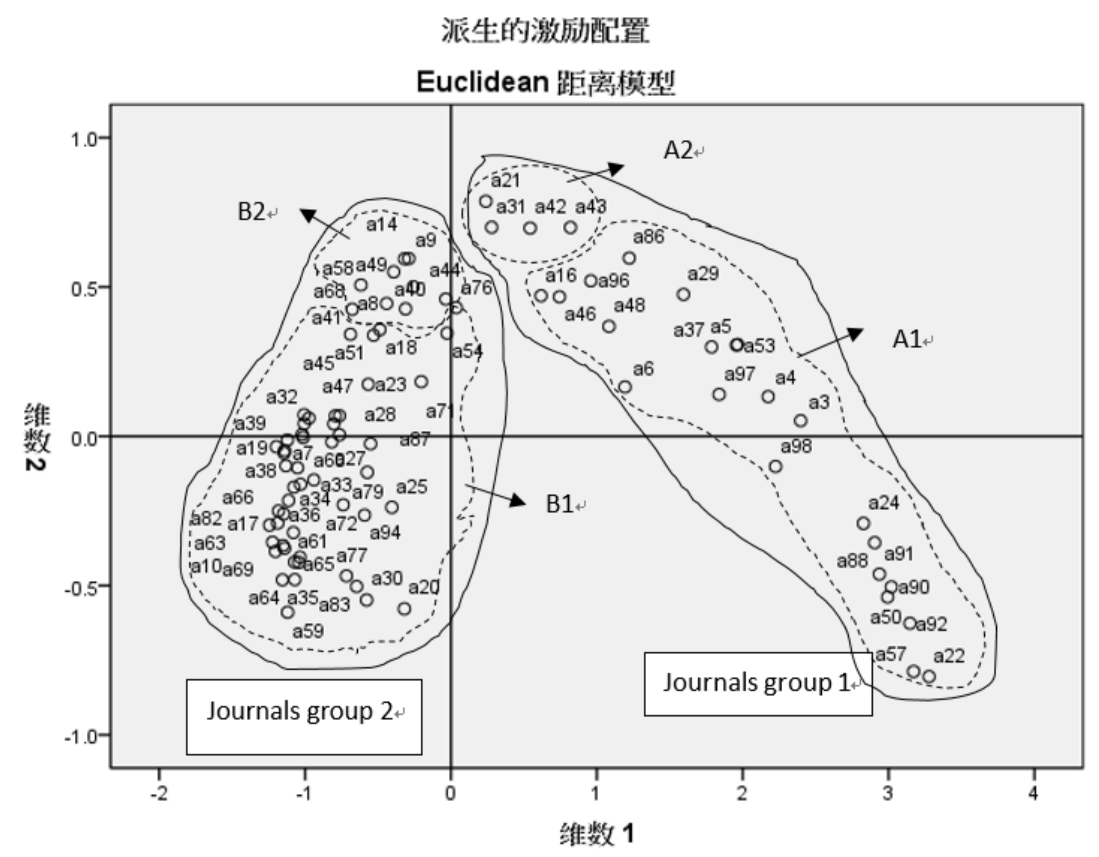

Fig. 3. The co-citation map of 86 important crop science journals

\section{Conclusions}

According to the result of Journal Citation analysis and co-citation mapping knowledge, we can see that the international crop science research can be divided into two parts in recent years. The first part focus on plants (crops) own research (Journal Group 2), including plant physiology, plant ecology, plant cells, etc. and biochemistry and molecular biology, gene and genetics, etc., which is mainstream areas and more concerned by crop science researchers now. Another part is more concerned about the relationship between plants (crops), soil, resources and environment, including crop production, soil science and environment science, which is another important branch of crop science. In addition, some journals of resource and environment, horticulture, crop protection, food processing, animal husbandry are found to be highly cited by crop science journals, which proves that interdisciplinary integration between crop science and other subjects, and the journals from these areas have become the journals concerned by crop researchers.

Overall, the journal co-citation analysis is an effective method for revealing core journals of disciplines. Journals co-citation analysis can reveal the structure of discipline by the way of cited journals co-citation analysis, which is from the perspective of the journal analysis. Thus, through the journal position in the different disciplines, we can judge core journals of different subjects to help researchers to find more useful information ${ }^{[19]}$. Comparing with the previous research, the difference is 
that, it delineates the target journals group gradually spreading from a single female parent journal, namely in the way of using an important journal of crop science based on citation analysis to gradually delineate the subject core journals. From the result of International crop science related Journals co-citation analysis, it is satisfactory that it can reflect objectively the crop science underlying structure and core journals distribution by the journal co-citation analysis combined with visualization techniques. It is successful that the applied discipline is expanded.

However, when using the journal co-citation analysis, it must pay more attention on data collection and processing methods and process control, or it will have a direct impact on the accuracy of the analysis results. I believe that there are two aspects need to be taken seriously. One is periodical cleaning, which is necessary because the journals abbreviated titles may be not unified and some journal title may change, so inattention could cause distortion of data and affect the final results. The other one is the choice of the study object, factor analysis, clustering and multidimensional scaling method and the error of statistical analysis, which will affect the results objectivity, so it must carefully plan in order to ensure effective and objective analysis of the results. In the future studies, we will continue to combine journal published papers and the integration of new technologies and analysis methods to explore more accurate and reliable methods of revealing potential knowledge structure and core journal distribution in different fields.

\section{Acknowledgment}

Funds for this research was provided by the Chinese Academy of Agricultural Sciences Science and Technology Innovation Projects (CAAS-ASTIP-2015-AII).

\section{References}

1. Wan J.M. The development direction of crop science "11th five-year plan" in China[J]. Crops,2006,01:1-4. (in Chinese)

2. Small H. G. Co-citation in the scientific literature: A new measure of the relationship between two documents [J]. Journal of the American Society for information Science, 1973,24:265-269.

3. Small H. G.et al. Clustering the science citation index using co-citations II: mapping science. Scientometrics [J].1985,8:321-340.

4. Small H. G. Multiple citation patterns in scientific literature: the circle and hill models [J]. Information storage and trisval,1974,10:393-402.

5. Small H. G. The relationship of information science to the social science: A co-citation analysis [J]. Information prooving and management, 1981,17:39-50.

6. White H. D., Grifflth B.C. Author co-citation: A literature measure of intellectual structure [J]. Journal of the American Society for Information Science, 1981,32:163-171.

7. White H. D. A co-citation map of the social indicators movement [J]. Journal of the American Society for Information Science, 1983,34:307-312. 
8. White H. D., Grifflth B.C. Authors as markers of intellectual spaces: Co-citation in studies of science, technology and society [J]. Journal of Documentation,1982,38,255-272.

9. Miyomato S., Nakayama K. A technique of two-stage clustering applied to environment and civil engineering and related methods of citation analysis [J]. Journal of the American Society for Information Science, 1983,34:192-201.

10. K.W. McCain. Mapping economics through the journal literature: An experiment in journal co-citation analysis [J]. Journal of the American Society for Information Science, $1991,42(2): 290-296$.

11. Y. Ding, G. G. Chowdhury, S. Foo. Journal as markers of intellectual space: Journal cocitation analysis of information Retrieval area,1987-1997[J]. Scientometrics,2000,47(1): 5573.

12. M. Y. Tsay, H. Xu, C. W. Wu. Journal co-citation analysis of semiconductor literature[J].Scientometrics,2003,57(1):7-25.

13. Z. Liu. Visualizing the intellectual structure in urban studies: A journal co-citation analysis (1992 -2002)[J]. Scientometrics,2005,62(3):385-402.

14. I. Marshakova-Shaikevich, Bibliometric maps of field of science [J].Information Processing \& Management, 2005, 41 (6) :1534-1547.

15. Hou H.Y. International Measurement Science core journals and knowledge map $[\mathrm{J}]$. Chinese Journal of Scientific and Technical Periodicals,2006,17(2):240-243. (in Chinese)

16. Qiu J.P. Zhao W.H. A Metric Demonstration of Journal Co-citation [J]. Information Science, 2008,26(10):1447-1450. (in Chinese)

17. Zhao Y. International Biohydrogen Key Periodical co-citation analysis and mapping knowledge[J]. Chinese Journal of Scientific and Technical Periodicals,2009,20(6):1043-1045. (in Chinese)

18. Zhao Y., Sun C. Q., Sha Y.Z. The Knowledge Mapping Analysis on the Research of Biohydrogen[J].China Biotechnology,2009,29(1):116-121(in Chinese)

19. Zhao Y. Visualizing a Discipline:Journal Co-citation Analysis of Library and Information Science[J]. Library and Information,2009,(3):89-94. (in Chinese)

20. Qin C.J. The Empirical Research of the Knowledge Domains Map Between Subject Relationship Based on Journal Co-citation Analysis Method [J]. Journal of Modern Information,2010,30(5):9-11. (in Chinese)

21. Liang Y.X., Yang Z. K., Liu Z.Y. Citation disciplinary status analytics[J]. Information Studies:Theory \& Application,2010,33(5):18-20. [6]Zhao D.Z. Journal Co-citation Analysis: A method of Research and the Journal of the structure and characteristics [J]. Chinese Journal of Scientific and Technical Periodicals,1993,4(1):55-58. (in Chinese)

22. Zhao D. Z. Journal co-citation analysis: a method of research discipline and the structure and characteristic of journals. Chinese Journal of Scientific and Technical Periodicals, 1993,4 (1):55-58. (in Chinese)

23. Qiu J.P. Information metrology(11)--Lesson Information metrology in the field of Library and Information Science-A Case Study on Core Journals and determination[J]. Information Studies: Theory \& Application,2001,24(5):396-400. (in Chinese)

24. Hou H.Y. Mapping Evolution of Scientometries[J]. DaLian,Dalian University of Technology,2006. (in Chinese)

25. Yang L.J., Zhang L.Y. An Empirical Research of the Diagonal Values of Journal Cocitation Matrix[J]. Library and Information Service,2010,54(4):144-148. (in Chinese) 